\title{
CREATIVE ECONOMY ON E-WAROENG KUBE
}

\author{
Erti Dinihayati ${ }^{1}$, Yanti Purwanti ${ }^{2}$ \\ ${ }^{1,2}$ Universitas Pasundan, Bandung, West Java, Indonesia \\ Iertidinihayati@unpas.ac.id \\ 2yanti.purwanti@unpas.ac.id
}

\begin{abstract}
Creative economy is the creation of added value (economic, social, cultural, environment) based on ideas that are born from the creativity of human resources (creative people) and based on the use of knowledge, including cultural and technological heritage. Creativity is not limited to works based on art and culture, but can also be based on science and technology, engineering and telecommunications. There are 3 main things that are the basis of the creative economy, including creativity, innovation and discovery. E-warong KUBE is a community empowerment program in the economic field and through the Prosperous Indonesia Community Card issued by BNI is expected to empower the poor to achieve a prosperous society. This program facilitates economic transactions for residents receiving the Family Hope Program (PKH). The amount of non-cash food aid is Rp. 110,000.0 / KPM / month, the assistance cannot be collected in cash, and can only be done with rice and / or eggs in e-warong. If assistance is not spent in that month, the value of assistance will still be stored and accumulated in the Food Aid Electronic Account. The aim of KUBE e-waroeng can be achieved through increasing the ability or empowerment of families and communities, as well as increasing community access to social resources in the community so as to foster creativity, innovation and discoveries that can make e-waroeng have economic value to realize development a sustainable economy based on creativity.
\end{abstract}

\section{Keyword : Creative Economy, KUBE E-waroeng, Creativity}

\section{Introduction}

Development is an effort made by the government, the business world, and the community through the provision of guidance and reinforcement assistance to grow and improve the ability of small business enterprises to become strong and independent businesses. One mandate of Law Number 13 Year 2011 concerning Handling the Poor is the existence of social security, social empowerment, and social rehabilitation in developing, developing, and empowering themselves and their families. Based on the Integrated Database, the number of families with poor criteria is $27,670,069$ households or $92,994,742$ people, the data is dynamic and every 6 (six) months data verification and validation is verified. The Ministry of
Social Affairs cooperates with the Association of State Banks (Himbara), namely BNI, BRI opened a warung which is connected to the internet or called e-Warong KUBE PKH which is mostly located in villages and small alleys. Electronic Gotong Royong KUBE PKH (e-Warong KUBE $\mathrm{PKH})$ is a place of business and agency that is managed and owned by the poor people who receive KUBE programs.

e-warong is still unable to handle business risks, especially none of which are sold in stalls other than KPM and consumers are visited by consumers at the time of disbursement of non-cash food aid. The dynamics of the group are very low among e-warong businesses, although many members have arranged picket 
schedules in the warung, but members have to sacrifice a lot of time with low income. The head of e-warong is a shop owner who is mostly unwilling to share the trust by lending the warung's key, this shows there is no freedom within the group to do business.

E-warong has good potential to be developed but must be accompanied by the formation of active group dynamics with the growth of trust among members. The existence of good group dynamics can increase the sense of ownership of the stalls and increase the entrepreneurial spirit to keep the stalls serving the buyers, and gradually increase the products sold or produce their own products that can be marketed in the stalls.

In the creative economy, the government (regulator) and company (operator) require a separate paradigm in determining policy and management. Bandung city is known as an art city whose people have high creativity, both in terms of unique fashion designs, to food creations that always experience the latest developments. Responding to the new paradigm is the fact that creativity, knowledge and access to information are increasingly being recognized as a driving force supporting economic growth and promoting global development. The emerging creative economy has become an important component in economic growth, the provision of employment, trade and innovation, and social cohesion in most developed countries. The Creative Economy will become a world economic trend in the next few years. The stagnation of economic growth and environmental degradation are increasingly worrying, encouraging the whole world to put forward creativity in economic life that maximizes the added value of goods and services in order to sustain life and human civilization.

\subsection{The concept of e-Warong KUBE}

The Joint Business Group (KUBE) as a community empowerment program to reduce poverty needs to be assessed. Various suggestions are considered as to which aspects of group work should be assessed, how individual contributions to the group can be measured, and what approaches should be used when evaluating the quality and quantity of a group's output. (Galton, 2010)

E-warong is a term used in the Non-Cash Assistance Program to refer to bank agents, traders and / or other parties who have worked with distribution banks and determined as a place to purchase foodstuffs by Beneficiary Families (KPM), namely traditional markets, stalls , grocery stores, KUBE e-warong, Village Stalls, Our Food Houses (RPK), Smart Behavior Agents, Digital Financial Service Agents (LKD) that sell food or other retail businesses.

E-warong is a community empowerment program in the economic field and it is hoped that through the Prosperous Indonesia Community Card issued by BNI, it is hoped that the empowerment of the poor to a prosperous society can be realized. This program facilitates economic transactions for residents receiving the Family Hope Program (PKH). The amount of non-cash food aid is Rp. 110,000.0 / KPM / month, the assistance cannot be collected in cash, and can only be done with rice and / or eggs in e-warong. If assistance is not spent in that month, the value of assistance will still be stored and accumulated in the Food Aid Electronic Account.

\subsection{Partnership Pattern}

The partnership pattern between various parties (user community, suppliers, banking and social assistance) in the implementation of KUBE e-warong is important in the success of this program. Non-Cash Food Aid Distribution Bank, in this case BNI 46, is a government partner bank that distributes food aid funds to the Beneficiary Families (KPM).

Partnership is a general partnership is a form of business organization in which two or more business owners share the management and risk of the business "Coulter (2000: 137). Based on this theory it can be stated that there are two important things as keywords in partnerships, namely: 1) Business governance (management of the 
business), and 2) Handling business risk (risk of the business).

The active role of the business world is needed in efforts to alleviate poverty and empowerment (Untung, 2008: 35), one of which is realized by PT. Bank Negara Indonesia (Persero) Tbk or BNI in the form of a stall business development that can do digital transactions or KUBE e-stalls. KUBE stalls can be developed as BNI46 (Branchless Banking) agents in order to gain benefits or add value as BNI46 agents. Additional services at this KUBE shop can also expand the business network associated with various means of payment such as electricity, telephone to credit. The establishment of BNI46 agents is one part of BNI's support for financial inclusion and literacy improvement programs developed by the Financial Services Authority (OJK). BNI has set up an integrated aid distribution system using IT facilities by issuing Combo cards, which are payment instruments that have electronic financial and savings features that can be used as a distribution medium for various social assistance.

Business organizations as complex centers of community-building replete with economic and social goals. (Ridley-Duff, 2008). Social and economic policies are also very important to assist KUBE in dealing with problems in partnerships, especially those related to managing business risks. Social and economic policies that would defend the socio-economically disadvantaged against an accumulation of risk in the critical periods of their life. It highlights survival strategies for social work in a marginalizing practice environment (Orovwuje, 2001). An important strategy in the implementation of KUBE e-stalls is related to social enterprise, namely the ability to follow current business movements that lead to increased e-literacy capabilities in the Social Assistance distribution system as a social network.

Social dimensions of networks affect the transfer of knowledge capital between network members. (Inkpen\& Tsang, 2005), where Social alliance is one of the patterns that support the use of resources. Some of the observed patterns support prior research and are in line with the resource dependence and institutional perspectives. (Sakarya et al., 2012). Contributions from social alliance will affect the social responsibility of the KUBE chairman as a manager. Value systems and styles of social responsibility of managers have gone through three historical phases. (Hay \& Gray, 1974). The social responsibility of the KUBE chairman must reach the improvement of the quality of life of the members.

\subsection{Community development}

The aim of KUBE e-warong is to achieve economic and social empowerment, the concept of empowerment is broadly conveyed by Zastrow (2015: 52): "The process of helping individuals, families, groups and communities to increase their personal, interpersonal, socioeconomic, and political strength and to develop influence toward improving their circumstances.

The indicator that KUBE is politically empowered is in the form of government policies that protect it. The business case needs to be supplemented by strong, proactive legislation, and worker involvement (Hart, 2010). Community empowerment focuses on the ability of kelayan to utilize the resources and strengths they have. Empowerment is an increasing decision making discreation of individuals. Coulter (2000: 152). Empowerment means in accordance with the objectives of KUBE as an organization, where the KUBE chairman must have transformational leadership.

Transformational leadership was positively related to empowerment, group cohesiveness, and group effectiveness. (Jung \&Sosik, 2002). KUBE e-warong empowerment correlates with group cohesiveness and transformational leadership. A transformational leader will try to continuously establish social networkers. Empowerment also follows the IPO (Input-Process-Output) framework. (Mathieu et al., 2006). Creativity as an important part of entrepreneurship also influences empowerment.

\subsection{Creative Economy Terms}


The term creative economy develops from the concept of creativity-based capital that can potentially increase economic growth in an area. According to President Susilo Bambang Yudhoyono in AgungPascasuseno (2014), "the creative economy is the fourth wave economy in which the continuation of the third wave economy is oriented towards creativity, culture, and cultural and environmental heritage".

Creative economy is a concept for realizing sustainable economic development based on creativity. Utilization of resources that are not only renewable, even unlimited, namely ideas, ideas, talents or creativity and creativity. The economic value of a product or service in the creative era is no longer determined by raw materials or production systems as in the industrial era, but rather the use of creativity and innovation creation through increasingly advanced technological developments. The industry can no longer compete in the global market by only relying on price or product quality, but must compete based on innovation, creativity and imagination.

Quoting the Creative Economy Blueprint 2025 , creative economy is a creation of added value (economic, social, cultural, environmental) based on ideas born from the creativity of human resources (creative people) and based on the use of knowledge, including cultural and technological heritage. Creativity is not limited to works based on art and culture, but can also be based on science and technology, engineering and telecommunications. There are 3 main things that are the basis of the creative economy, including creativity, innovation and discovery.

Creative Economy as a driving force for the creation of a competitive Indonesia and quality of life society.

a. The competitiveness to be realized is a condition of a creative society, able to compete fairly, honestly and uphold ethics, excel at the national and global level, and have the ability (the struggle) to continue to make improvements (continuous improvement), and always think positively to face challenges and problems, b. Quality of Life to be realized is a happy condition of society, namely: physically and mentally healthy, educated, have awareness to preserve the environment, have a balanced life, have social care, have tolerance in accepting differences, and interpret values and wisdom local, cultural heritage, traditions wisely, able to develop and utilize culture, and make culture the basis for creating the identity and character of its nation.

The mission of the creative economy, among others, is to optimize the development and preservation of local resources that are competitive, dynamic, and sustainable. Then develop creative industries that are competitive, growing, diverse, and quality and develop a conducive environment that mainstreams creativity in national development by involving all stakeholders.

\subsection{Creative Economy Scope}

With the concept of the creative economy, the industrialization side can also be developed towards the creative industries. Creative industries are industries that produce output from the use of creativity, expertise, and individual talents to create added value, employment, and improving quality of life. The creative economy is often seen as an umbrella concept that is also another popular concept at the beginning of the 21 st century, namely the Creative Industry.

The definition of creative industries according to the Creative Industries Task Force, is "Creative Industries as those industries which have their origin in individual creativity, skills \& talents, and which have a potential for wealth and job creation through the generation and exploitation of intellectual property and content". ( Purnomo et al., Nd)

The definition of Creative Industries Task Force is the reference for the definition of creative industries in Indonesia as written in the Indonesian Creative Economy Development Plan Book 2009-2015 issued by the Ministry of Trade of Indonesia (2008) as follows: "Creative industries derived from the use of creativity, skills and talents individuals to create welfare and employment through the creation and 
utilization of the creative power and creativity of these individuals. "

Sub-sectors which are creativity based industries in Indonesia based on the mapping of creative industries that have been carried out by the Ministry of Trade of the Republic of Indonesia are:

1. Advertising: creative activities related to advertising services (one-way communication using certain media), which includes the process of creation, production and distribution of advertisements produced, for example: market research, advertising communication planning, outdoor advertising, production of advertising materials, promotions, public relations campaigns, display advertisements in print media (newspapers, magazines) and electronics (television and radio), installation of various posters and pictures, distribution of leaflets, pamphlets, circulars, brochures and similar advertisements, distribution and delivery of advertising materials or samples, as well as renting columns for advertisements. KBLI Code (Business Field Standard Classification) 5 digits; 73100

2. Architecture: creative activities related to building design services, construction cost planning, conservation of heritage buildings, overall construction supervision from the macro level (Town planning, urban design, landscape architecture) to the micro level (construction details, for example: architecture garden, interior design). KBLI Code (Business Field Standard Classification) 5 digits; 73100

3. Art Goods Market: creative activities related to trade in authentic, unique and rare goods and have a high artistic aesthetic value through auctions, galleries, shops, supermarkets, and the internet, for example: musical instruments, printing, crafts, automobiles film, fine arts and painting.

4. Crafts: creative activities related to the creation, production and distribution of products made by craftsmen starting from the initial design to the process of product completion, including but not limited to handicrafts made of: precious stones, natural or artificial fibers, leather rattan, bamboo, wood, metal (gold, silver, copper, bronze, iron) wood, glass, porcelain, cloth, marble, clay, and lime. Craft products are generally only produced in relatively small quantities (not mass production).

5. Design: creative activities related to graphic design creations, interior design, product design, industrial design, corporate identity consulting and marketing research services as well as packaging production and packaging services.

6. Fashion (fashion): creative activities related to the creation of clothing designs, footwear designs, and other fashion accessories design, production of fashion apparel and accessories, consultancy of fashion product lines, and distribution of fashion products.

7. Video, Film and Photography: creative activities related to the creation of video production, film and photography services, as well as the distribution of video and film recordings. This includes film production management, script writing, cinematographic management, artistic arrangement, sound management, image editing, soap operas, and film exhibitions.

8. Interactive Games: creative activities related to the creation, production, and distribution of computer and video games that are entertainment, agility, and education. The interactive game subsector is not dominated as mere entertainment but also as a learning or educational aid.

9. Music: creative activities related to the creation / composition, performance, reproduction, and distribution of sound recordings.

10. Performing Arts: creative activities related to content development, performance production (eg ballet performances, traditional dances, contemporary dance, drama, traditional music, theater music, opera, including ethnic music tours), design and manufacture of performance clothing, stage, and lighting.

11. Publishing and Printing: creative activities related to content writing and publishing of books, journals, newspapers, magazines, tabloids, and digital content as well as news agency activities and news seekers. This sub-sector also covers the issuance of stamps, stamps, banknotes, blank checks, demand deposits, share certificates, bond securities, other securities, passports, 
airplane tickets, and other special issues. Also includes publishing photographs, engraving and postcards, forms, posters, reproductions, painting printing, and other printed matter, including micro-film footage.

12. Computer and Software Services: creative activities related to information technology development including computer services, data processing, database development, software development, system integration, system design and analysis, software architecture design, software infrastructure design and software hard, as well as portal design including maintenance.

13. Television and Radio: creative activities related to the creation, production and packaging of television programs (such as games, quizzes, reality shows, infotainment, etc.), broadcasting, and transmission of television and radio program content, including station relay activities (transmitters back) radio and television broadcasts.

14. Research and Development: creative activities related to innovative businesses that offer the discovery of science and technology and the application of these knowledge and knowledge to improve products and the creation of new products, new processes, new materials, new tools, new methods, and new technologies that can meet market needs; including those relating to humanities such as research and development of language, literature, and art; and business and management consultancy services.

15. Culinary: this creative activity including new, in the future is planned to be included in the creative industry sector by conducting a study of the mapping of Indonesian processed food products that can be improved competitiveness in the international retail and market markets. The study was conducted to collect data and information as complete as possible about processed food products typical of Indonesia, to be disseminated through appropriate media, at home and abroad, so as to gain increased competitiveness in modern retail markets and international markets. The importance of this activity is based on the fact that Indonesia has a cultural heritage of distinctive food products, which is basically a source of comparative advantage for Indonesia. It's just that, the lack of attention and attractive management, making the comparative advantage not explored into more economic value. Creative economic activities as an initiative with a pattern of small cost thinkers but have a wide market share and are in demand by the wider community including culinary business, accessories, screen printing, embroidery and small people's businesses such as sellers of bala-bala, meatballs, comro, gehu, batagor, bajigur and ketoprak.

\section{Method}

The method used is a quantitative method with respondents as a source of information is the management of KUBE e-waroeng which in Bandung totaling 76 e waroeng with census data collection techniques using a research instrument in the form of a questionnaire.

The data processing technique uses analysis factor to see which variable has the biggest impact on KUBE e-waroeng by looking at the variables of creativity, innovation and discovery as three main points in the creative economy.

\section{Results and Discussion.}

The results showed that $57.6 \%$ of respondents of e-warong leaders from the city of Bandung all of them expressed disagreement with the statement stating that the e-warong leaders had the business ability to develop the KUBE e-warong, the answer to the statement showed that the administrators and their e-warong members don't have the creativity to develop their own e-warong.

Creativity to develop e-warong is the basic capital that must be owned by the management and members of e-warong because having business creativity will open their knowledge about the function and function of the e-warong, in this case the supervisor or assistant only provides input on how and what efforts can be made to develop the e-warong which is a milestone for the implementation of the e-warong's 
retreat is the members and administrators of the e-warong.

The results of the study above show, there were $63.6 \%$ of respondents of e-warong leaders from the city of Bandung, all of them said they did not agree with the statement stating that the e-warong leaders had the integrity to develop the KUBE e-warong, the answer to the statement showed that the management and e-warong members who are their respondents do not have the integrity to develop their respective ewarong.

Integrity is a concept related to consistency in the actions, values, methods, measurements, principles, expectations and various things produced. People with integrity means having an honest person and having a strong character ... to develop this e-warong business it is expected that the leaders and administrators of their e-warong must have integrity or honest actions and have a strong character, because the development of e-warong depends the integrity or character of the administrators and e-warong leaders themselves.

The results also showed that almost $60.0 \%$

KMO and Bartlett's Test

\begin{tabular}{llr}
\hline \multicolumn{2}{l}{ Kaiser-Meyer-Olkin Measure of } &, 830 \\
Sampling Adequacy. & Approx. Chi-Square & 28,930 \\
Bartlett's & df & 3 \\
Test of & df &, 000 \\
Sphericity & Sig. &
\end{tabular}

of respondents from e-warong leaders from Bandung City stated that they disagreed if it was said that KUBE e-waronghad a network of information about store agents for certainty of food stock,

In accordance with the KUBE PKH ewarong implementation guidelines, the distributors so far played by Bulog are the institutions responsible for providing staple food in guaranteed quantities and quality, and at affordable prices. In carrying out their duties, distributors work closely with KMIS and banks through formal agreements to develop an effective and efficient supply and payment system. The ordering of goods is done centrally by KMIS to be distributed to e-Warong at a price lower than the price of the surrounding stalls but in reality on the ground, all KUBE e-warong work independently are not dependent on the Bulog all goods supplier networks are managed by the e-warlord stalls or supervisors, as well as ownership of information networks about suppliers / distributors for food stock certainty.

The results of the above study showed $59.4 \%$ of e-warong leaders from the city of Bandung did not have cooperation with store agents for certain food stock. The results of the field show that not all of their e-warong leaders have innovations to collaborate with shop agents for certainty of food stock because buying at shop agents is more expensive so that the leaders of e-warong they have cooperation for certainty of their food stock directly with distributors or suppliers directly related to the e-warong itself do not go through the store agent first, the next question regarding cooperation with suppliers or distributors to ensure food stock.

The results showed that not all KUBE ewaroeng in Bandung had creativity, innovation and discovery for the development of KUBE e-waroeng towards the vision, mission of the creative economy. To see the contribution of each variable, an analysis factor is used. From the calculation results obtained as follows:

Based on the above output we can know the value of $\mathrm{KMO}=0.830>0.50$ and the value of Bartlett's Test of Sphericity (Sig) 0,000 $<0.05$, it can be seen that the variables of creativity, innovation and discovery can be used as variables that can be processed further.

Communalities

\begin{tabular}{lrr}
\hline & Initial & Extraction \\
\hline Creativity & 1,000 &, 857 \\
Inovation & 1,000 &, 814 \\
Finding & 1,000 &, 918 \\
\hline
\end{tabular}

Extraction Method: Principal

Component Analysis.

The table above shows how much a variable can explain a factor. Based on the output, it can be seen that the discovery variable can explain a factor of $91.8 \%$ to the e-waroeng development factor, then 
the creativity variable is $85.7 \%$ and the innovation variable is $81.4 \%$. This shows that basically e-waroeng already has a discovery for the development of its business, although it has not found a meaningful innovation, this is because of the low background of knowledge and skills of the KUBE e-waroeng chairmen.

a. Creativity Can be described as a capacity or ability to produce or create something that is unique, fresh, and generally acceptable. It can also generate new or practical ideas as a solution to a problem, or do something different from the existing one (thinking out of the box). Someone who has creativity and can maximize that ability, can create and produce something useful for himself and others.

b. Innovation A transformation of ideas or ideas based on creativity by utilizing existing inventions to produce a product or process that is better, added value, and useful. As an example of innovation, try to see some innovations in youtube.com videos with the keyword "lifehack". The video shows how a product that already exists, is then innovated and can produce something that has higher sales value and is more useful.

c. Invention. This term emphasizes more on creating something that has never existed before and can be recognized as work that has a unique function or has never been known before. Making applications based on Android and iOS is also an example of technology and information-based inventions that greatly facilitate humans in carrying out daily activities.

The expected economic condition is a sustainable economy and also has several sectors as pillars and supports of economic activity in Indonesia. Sustainability in question is the ability to adapt to geographical conditions and new economic challenges, which ultimately results in sustainable growth.

\section{Conclusions}

1. e-warong is still not able to handle business risks, especially those that are not sold in stalls other than KPM and consumers are visited by non-cash food aid customers. The head of e-warong is a shop owner who is mostly unwilling to share his trust by lending the warung's key, this shows there is no freedom in the group to do business.

2. e-warong has good potential to be developed but must be accompanied by the formation of active group dynamics with the growth of trust among members. The existence of good group dynamics can increase the sense of ownership of the stalls and increase the entrepreneurial spirit to keep the stalls serving the buyers, and gradually add the products sold or produce their own products that can be marketed in the stalls.

3. e-waroeng can produce a sustainable economy and in accordance with the vision, mission of the creative economy if supported by ongoing guidance and monitoring from the parties concerned.

4. The main challenge faced in developing the structure of the national economy in the future is to accelerate efforts to strengthen the structure of the Indonesian economy with the core of e-warong as the main driver of economic growth, which is pro-poverty reduction and increasing business opportunities.

5. e-warong explicitly states the objectives of the development and development of e-warong are: (1) growing and improving the ability of e-warong into a strong and independent business and can develop into an independent business, and (2) increasing the role of $e$ waroengin forming national products, expanding employment and business opportunities, increasing exports, and increasing income distribution to realize itself as the backbone and strengthen the structure of the national economy.

\section{References}

\section{DIREKTORAT JAMINAN SOSIAL DIREKTORAT JENDERAL PERLINDUNGAN DAN JAMINAN SOSIAL KEMENTERIAN SOSIAL, BUKU KERJA PENDAMPING DAN OPERATOR PKH. Indonesia: DIREKTORAT \\ Galton, M. (2010). Assessing group work. In}


International Encyclopedia of

Education (pp. 342-347).

https://doi.org/10.1016/B978-0-08-

044894-7.00356-0

Hart, S. M. (2010). Self-regulation, corporate social responsibility, and the business case: Do they work in achieving workplace equality and safety? Journal of Business Ethics, 92(4), 585-600.

https://doi.org/10.1007/s10551-0090174-1

Hay, R., \& Gray, E. (1974). Social

Responsibilities of Business

Managers. Academy of Management

Journal, 17(1), 135-143.

https://doi.org/10.2307/254777

Inkpen, A. C., \& Tsang, E. W. K. (2005).

Social capital networks, and

knowledge transfer. Academy of

Management Review, 30(1), 146-165.

https://doi.org/10.5465/AMR.2005.15 281445

Jung, D. I., \& Sosik, J. J. (2002).

Transformational Leadership in Work Groups: The Role of Empowerment, Cohesiveness, and Collective-Efficacy on Perceived Group Performance. Small Group Research, 33(3), 313336.

https://doi.org/10.1177/104964020330 03002

Mathieu, J. E., Gilson, L. L., \& Ruddy, T. M. (2006). Empowerment and team effectiveness: an empirical test of an integrated model. The Journal of Applied Psychology, 91(1), 97-108. https://doi.org/10.1037/00219010.91.1.97

Orovwuje, P. R. (2001). The business model and social work: a conundrum for social work practice. Social Work in Health Care, 34(March 2014), 59-70. https://doi.org/10.1080/009813801095 17017

Purnomo, R. A., Si, M., \& Indonesia, P. P. (n.d.). Ekonomi Kreatif.

Ridley-Duff, R. (2008). Social enterprise as a socially rational business.

International Journal of

Entrepreneurial Behaviour and

Research, 14(5), 291-312.

https://doi.org/10.1108/135525508108 97669

Sakarya, S., Bodur, M., Yildirim-??ktem, ??zlem, \& Selekler-G??ksen, N. (2012). Social alliances: Business and social enterprise collaboration for social transformation. Journal of Business Research, 65(12), 17101720. https://doi.org/10.1016/j.jbusres.2012. 02.012

Y. Sariningsih and U. P. Bandung, "Kreativitas dan inovasi pelaku kube," vol. 1, no. 1, pp. 18-37, 2018. 